\title{
Prihodnost izobraževanja odraslih v Evropi - melodološki pristop in opis vzorca raziskave
}

Sabina Jelenc

\begin{abstract}
Primerjalna raziskava o problemih, ciljih, ponudbi in politiki izobraževanja odraslih. Raziskava je del evropskega projekta Izobraževanje odraslih v Evropi 1995, ki ga vodi prof. dr. Walter Leirman iz Catholic University v Leuvenu (Belgija).
\end{abstract}

\section{Slovenija}

$V$ ta projekt je vključenih vseh 12 držav članic ES, poleg njih pa še Češka, Slovenija in Estonija. Projekt je nastal na podlagi ožje raziskave, imenovane Delphi - raziskovalni projekt izobraževanje 1992, ki so jo izvajali v letih od 1990 do 1992 na univerzi v Leuvenu v Belgiji. $Z$ njo so želeli ugotoviti osrednje cilje izobraževanja odraslih v devetdesetih letih, kako so se uresničili, poglavitne težave, ki se pojavljajo pri izobraževanju odraslih, ter osrednje naloge izobraževalne politike $\mathrm{v}$ državi.

Ugotovitve so bile tako zanimive, da je Evropska skupnost podprla izvedbo projekta v omenjenih državah.

Delo v projektu je potekalo po raziskovalni metodi Delphi, na kateri sta temeljila tudi oba belgijska raziskovalna projekta, izve-. dena v letih od 1990 do 1992 , ki sta bila podlaga za razširitev na države evropske skupnosti ter Češko, Estonijo in Slovenijo.

$S$ prvim belgijskim projektom so ugotavljali učne potrebe odraslih, kako organizacije za izobraževanje odraslih te potrebe uresničujejo ter kakšna je politika izobraževanja odraslih oziroma stopnja usklajenosti te politike.

Prvi projekt je zajel približno 300 posameznikov s področja izobraževanja odraslih v Flandriji. Vsak od njih se je, glede na vlogo, ki jo v izobraževanju odraslih ima, umestil v eno ali več skupin strokovnjakov: med politike, raziskovalce/teoretike, izobraževalce ali komentatorje. Vsak od njih je hkrati opredelil, na katerem področju (ali več področjih) izobraževanja odraslih je dejaven:

- osnovno izobraževanje odraslih,

- poklicno izobraževanje mladih (15-21 let),

- poklicno izobraževanje zaposlenih in brezposelnih odraslih,

- splošno izobraževanje odraslih,

- izobraževanje starejših.

Da bi raziskava potekala po metodi Delphi, katere osnovno načelo je konsultacija strokovnjakov nekega področja po metodi ciklicnega procesa zbiranja podatkov/spraševanja, analize in povratne informacije, so v treh krogih ponavljali razprave o dobljenih rezultatih. Po končanem opisanem postopku so rezultate zbrali.

S tem pa se raziskava še ni končala, saj so organizirali srečanje za vse, ki so vprašalnik izpolnjevali ali ki jih je ta tematika zanimala. Razpravljali so o rezultatih, o usmeritvah za prihodnost in dali konkretne predloge. Šele po tem so izdali končno poročilo o raziskavi.
Podobno raziskavo, vendar v ožjem merilu, so nato izvedli tudi $\mathrm{v}$ francosko govoreči belgijski skupnosti, pri čemer so uporabili enak (prilagojen) vprašalnik, podatke pa so zbirali le v enem krogu. Organizirali so sklepni kolokvij in pripravili končno poročilo.

Aplikacija metode Delphi na druge države Evropske skupnosti ter Ceško, Estonijo in Slovenijo je temeljila na uporabi francoske različice raziskave, torej skrajకane oblike. Koraki so naslednji:

1. V vsaki državi se ustanovi nacionalni svet, ki ga sestavljajo strokovnjaki $z$ vseh področij izobraževanja odraslih. S svojimi predlogi pripravijo listo respondentov.

2. Ko so podatki zbrani, vsaka država pripravi nacionalni posvet/kolokvij, na katerega povabi vse, ki so v raziskavi sodelovali - respondente in nacionalni svet. Dobljene povratne informacije po potrebi umestijo $v$ raziskovalno poročlo.

3. Končna raziskovalna poročila omogočijo primerjavo stanja izobraževanja odraslih po Evropi in pripravo predlogov za uskladitev izobraževalne politike v Evropi.

4. Zađnji korak je evropska konferenca, na kateri pripravijo končno poročilo in predlagajo ukrepe za uresničevanje evropske politike izobraževanja odraslih.

\section{Izbira respondentov}

V Sloveniji je potekala priprava predlogov za izbor respondentov tako kot $\mathrm{v}$ drugih državah. Nacionalni svet je skušal pripraviti kar najbolj reprezentativen vzorec, kar pomeni približno usklajeno razporeditev respondentov $\mathrm{v}$ že omenjene štiri skupine strokovnjakov:

a) Strokovnjaki s področja oblikovanja politike v izobraževanju odraslih na ravni vlade ali večjih organizacij (strokovnjak za politiko izobraževanja odraslih - oblikovalci politike izobraževanja).

b) Strokovnjaki s področja študija in raziskovanja (osebje iz raziskovalnih središč, univerz, študijskih središč - raziskovalci).

c) Strokovnjaki iz prakse (osebe, ki se ukvarjajo $z$ neposrednim izobraževalnim delom $v$ praksi ali $z$ usposabljanjem drugih izobraževalcev - izobraževalci).

c) Strokovnjaki, ki o obravnavanih problemih kritično informirajo javnost (komentatorii). 
Pogosto posameznika ni bilo mogoče umestiti le $v$ eno kategorijo, kar se je kasneje izkazalo tudi pri njihovi lastni izbiri, ko so se nekateri umeščali v več kategorij hkrati.

Zgodilo pa se je tudi, da je nacionalni svet posameznika po lastni presoji uvrstil v drugo kategorijo, kot se je kasneje uvrstil sam.

Naslednje merilo, na katerega smo skušali biti pri izbiri respondentov čm bolj pozomi, je izbira strokovnjakov glede na področje, na katerem so še posebej dejavni. Ta področja so:

a) poklicno izobraževanje mladih, starih od 16 do 25 let, ih,

b) poklicno izobraževanje zaposlenih in brezposelnih odras-

c) osnovno izobraževanje odraslih (osnovna šola za odrasle, programi za odpravljanje funkcionalne nepismenosti),

c) splošno, socio-kulturno izobraževanje,

d) usposabljanje $v$ podjetjih ali drugih delovnih organizacijah,

e) izobraževanje na splošno.

Tudi tu je bilo posameznike težavno uvrstiti le v eno skupino, saj jih je lahko izbiral več, hkrati pa se je spet dogajalo, da smo ga pri izbiri uvrstili drugam, kot se je kasneje sam.

\section{Oblikovanje in sestava vprašalnika}

\section{Prilagoditev vprašalnika slovenskemu prostoru}

Tudi slovenski vprašalnik smo oblikovali po vzorcu, ki ga je pripravil evropski upravni odbor, temelji pa na vprašalniku, ki so ga uporabili v francosko govoreči skupnosti v Belgiji. Preoblikovanje vprasalnika je pripravil W. Leirman.

Razvoj vprašalnika je potekal postopno:

- odprta vprašanja, s katerimi so dobili šrok razpon odgovorov o težavah, s katerimi se srečujejo odrasli (Vprašanje je bilo: »Kaj menite, kateri so najpomembnejši problemi, s katerimi se srečujejo odrasli v devetdesetih letih? «), in odgovorov na druga vprašanja, ki so jih predstavili po prvem krogu anketiranja,

- v drugem krogu so odprta in zaprta vprašanja združili v kategorije,

$-v$ tretjem krogu pa so respondente seznanili z rezultati statistične in deskriptivne analize odgovorov iz drugega kroga in se pogovorili o možnosti uporabe vprašalnika v evropskem merilu.

V francosko govoreči skupnosti v Belgiji so uporabili vprašalnik, sestavljen iz odprtih in zaprtih vprašanj drugega in tretjega kroga flamske raziskave.

V vprašalniku, namenjenem raziskavi evropskih razsežnosti, so naredili nekaj manjših sprememb in dodali nekaj vprašanj, pomembnih za razširjeno raziskavo. Na voljo sta bila vprašalnika $\mathrm{v}$ angleškem in francoskem jeziku, ki sta služila kot podlaga za prilagoditev vprašalnika.

Pri sestavi slovenskega vprasalnika smo kot podlago vzeli vprašalnik v angleškem jeziku, ki smo ga prevedli in prilagodili slovenskemu prostoru. Večna vprasanj je ostala nespremenjenih, izpustili smo le nekaj kategorij, ki so bile vsebinsko in terminološko v našem prostoru neustrezne.

Vprašalnik je obsegal 37 strani in ga lahko dobite na Filozofski fakulteti na Oddelku za pedagogiko.

\section{Sestava slovenskega vprašalnika}

Prvi del-profil strokovnjaka

$\mathrm{V}$ tem delu smo spraševali strokovnjake, katera je njihova osrednja vloga v izobraževanju odraslih oziroma kje je njhovo mesto na tem področju, s katerimi posebnimi področji dela se ukvarjajo in kakšna je narava njihovega dela ter stopnja strokovnosti. V prvem delu vprašalnika smo spraševali tudi po starosti in spolu.

\section{Drugi del-problemi, cilji, ponudba}

Tu so strokovnjaki odgovarjali, $v$ kolikšni meri se odrasli srečujejo $\mathrm{z}$ določenimi problemi in koliko lahko izobraževanje odraslih pripomore $\mathrm{k}$ njihovemu razreševanju. Respondente smo tudi prosili, naj navedejo nekaj razlogov za majhen ali velik prispevek izobraževanja k razrešitvi omenjenih težav.

Respondente smo tudi prosili, naj presodijo in odgovorijo, koliko se jim zdijo navedeni cilji izobraževanja odraslih pomembni ter koliko časa in truda so namenili uresničvanju določenega cilja. Prosili smo jih za kratek opis poteka uresničevanja cilja, hkrati pa tudi za odgovor, ali so bile na njihovem področju uvedene kakšne novosti pri uresničevanju teh ciljev ter vsebino in razloge zanje.

\section{Tretji del - izobraževalna politika}

Strokovnjake smo prosili, naj nam odgovorijo, ali so po njihovem mnenju navedene naloge $v$ izobraževanju odraslih domena državnih organov, ali državni organi to nalogo dejansko opravljajo in kako dobro je njeno izvajanje.

Prosili smo jih tudi, da $\mathrm{z}$ navedenega seznama izberejo tri zakone, ki so povezani $z$ izobraževanjem odraslih, in o njih izrazijo svoje mnenje.

Ker v Sloveniji nimamo krovnega zakona o izobraževanju odraslih, smo strokovnjake povprǎ̌ali, ali si želijo, da bi ga imeli. Prav tako smo jih prosili, naj izrazijo svoje mnenje o tem, kdo naj bi bil v Sloveniji odgovoren za izobraževanje odraslih in ali bi morali sprejeti posebne zakone ali odloke za posamezna področja izobraževanja odraslih.

Vprašali smo jih, ali naj bi področje, na katerem delujejo, podpirali organi državne oblasti, zasebna pobuda ali oboji skupaj, ter kakšna bi bila najboljša rešitev za delovanje svetovalnih teles.

V tem sklopu vprašanj so tudi odgovarjali, kako naj bi izobraževalno ponudbo razširjali v Sloveniji - geografsko in tudi glede na druga merila. Iz seznama izobraževalne ponudbe so nato izbirali dve kombinaciji za sodelovanje, povedali, na kateri ravni bi to partnerstvo dobro delovalo, in predstavili kakšen konkreten primer.

Zadnje podrocje, o katerem smo jih spraševali, je bilo povezovanje in sodelovanje z Evropo. Strokovnjake smo prosili, naj navedejo, kako in koliko so se doslej že povezovali z Evropo in kakšno je njihovo videnje tega sodelovanja.

Sledila so le še vprašanja o zaželenosti in izvajanju politike za doseganje začetne kvalifikacije.

\section{Pošiljanje vprašalnikov}

Naš vprašalnik smo junija 1994 poslali 214 strokovnjakom z naštetih področij. Znova smo se na izbrane respondente obmili avgusta, $z$ vnovično prošnjo za vrnitev izpolnjenega vprašalnika.

Vrnjenih je bilo 86 vprašalnikov, 40 odstotkov.

Kot v drugih državah je bilo tudi v Sloveniji kar nekaj pritožb in negodovanja $v$ zvezi $z$ zahtevnostjo in pretirano podrobnostjo vprašalnika. Respondenti, ki se ukvarjajo z bolj specifičnimi področji izobraževanja odraslih, so izrazili zaskrbljenost glede izpolnitve vprašalnika, nekateri pa vprašalnika niso mogli ali želeli izpolniti do konca.

Glede na spremljajoč izjave respondentov sklepamo, da je bil vprašalnik za mnoge prezahteven, kar pomeni, da moramo biti na to pozorni tudi pri seznanjanju $\mathrm{z}$ rezultati. 


\section{Analiza podaktkov}

\section{Kvantitativna analiza}

Dobljene podatke smo kodirali po natančno določenem postopku in jih vnesli v sablono, ki je enaka za vse države. To je vodjem raziskave iz Leuvna omogočilo enotno statistično obdelavo podatkov za vse sodelujoče v mednarodni raziskavi.

Ko so nam iz Leuvna poslali obdelane podatke, smo na podlagi teh pripravili kvantitativno obdelavo in izdelali rezultate za poročanje.

\section{Kvalitativna analiza}

Poleg vprašanj, ki smo jih lahko kodirali po vnaprej določeni šabloni, smo klasificirali tudi odprta vprašanja oziroma odgovore, ki so jih respondenti napisali. $\mathrm{Z}$ vsebinsko analizo smo odgovore razvrstili po temah, smiselnih za posamezno vprašanje.

\section{Interprefacija odgovorov slovenskih respondentov}

\section{Profil strokovnjakov}

Vloga oziroma mesto strokovnjakov na področju izobraževanja odraslih (prvo vprašanje)

$\mathrm{V}$ prvem vprašanju so se respondenti morali opredeliti za eno ali več skupin strokovnjakov, ki smo jih določili glede na vlogo v izobraževanju odraslih.

Če se je posameznik pojavljal v več vlogah, jih je izbral več.

Kot kaže graf, se je največ respondentov opredelilo za izobraževalce; politiki in raziskovalci so si po zastopanosti blizu, komentatorjev pa je bistveno manj.

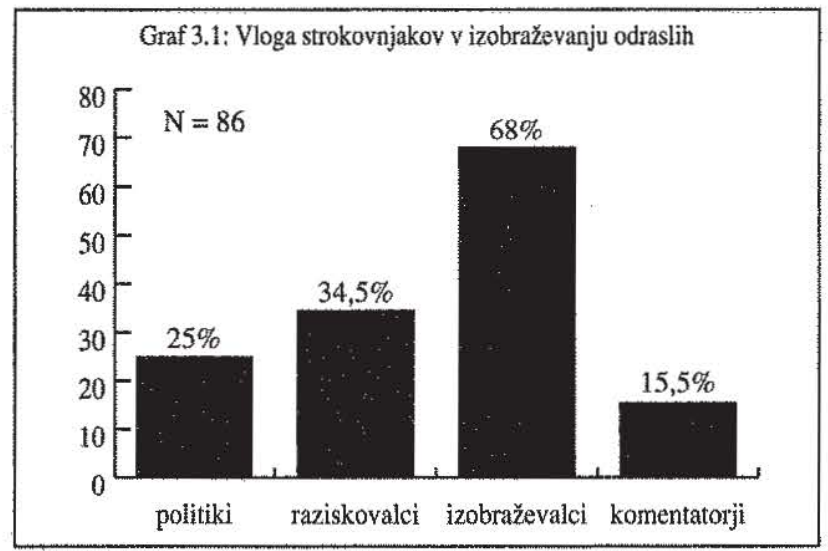

Rezultati so tudi posledica dejstva, da se je veliko respondentov opredelilo za več skupin.

1 respondent se je uvrstil v vse štiri skupine, 9 jih je izbralo tri izmed štirih, 44 pa se jih je uvrstilo v dve kategoriji od štirih, od tega se jih je 14 razvrstilo med raziskovalce in izobraževalce.

\section{Na katerih podroçjih izobraževanja odraslih so respondenti dejavni?}

Respondenti so tu izbirali po eno ali več področij, na katerih delujejo ali so aktivni. Vidimo, da se največ strokovnjakov (55 odstotkov) ukvarja s poklicnim izobraževanjem zaposlenih in brezposelnih odraslih, sledi usposabljanje v podjetjih ali drugih delovnih organizacijah, s katerim se ukvarja 45 odstotkov respondentov, približno enako se jih ukvarja s splosnim, sociokulturnim izobraževanjem kot s poklicnim izobraževanjem mladih
(16 do 25 let). Najmanj se jih ukvarja z osnovnim izobraževanjem odraslih ( 20 odstotkov), kar si lahko razlagamo tako, da so potrebe po tej vrsti izobraževanja velike, vendar pa je to področje slabo zastopano.

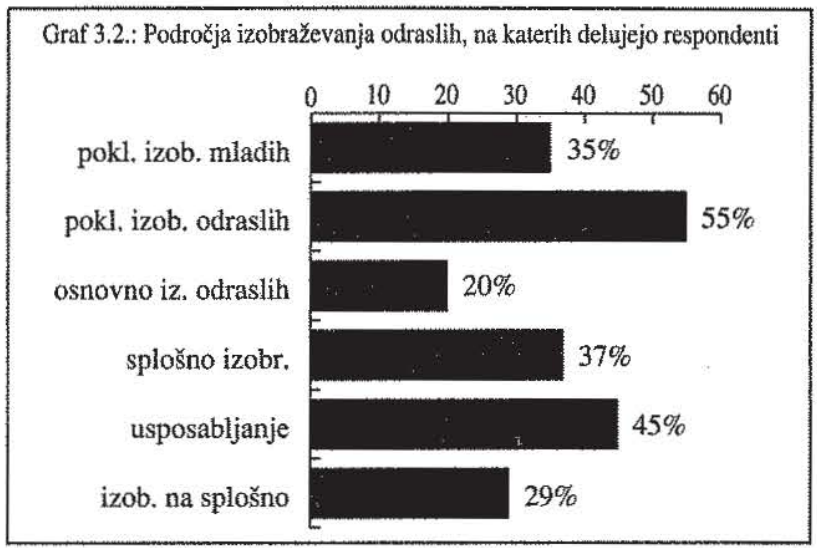

Spet vidimo, da so respondenti dejavni na več področjih hkrati. Tako so se za vseh šest področij odločili trije respondenti, na petih od šestih področij je aktivnih 23 respondentov, na štirih 73 respondentov, večina drugih strokovnjakov pa je aktivna vsaj na dveh področjih.

Poglejmo, koliko so posamezna področja zastopana glede na vlogo, ki jo ima posameznik v izobraževanju odraslih.

- Oblikovalci politike so najbolje zastopani pri poklicnem izobraževanju zaposlenih in brezposelnih odraslih, dejavni pa so tudi pri poklicnem izobraževanju mladih in pri usposabljanju $\mathrm{v}$ podjetjih ali drugih delovnih organizacijah. Njihov delež na drugih področjih je manjši.

- Raziskovalci so najbolj dejavni pri usposabljanju v podjetjih in drugih delovnih organizacijah, pri poklicnem izobraževanju zaposlenih in brezposelnih odraslih ter pri splošnem, sociokulturnem izobraževanju.

- Izobraževalci so najbolj vključeni v dejavnosti pri poklicnem izobraževanju zaposlenih in brezposelnih odraslih, pri usposabljanju in splošnem, sociokulturnem izobraževanju.

- Komentatorji pa so najbolj dejavni pri poklicnem izobraževanju mladih in poklicnem izobraževanju odraslih, pa tudi pri usposabljanju.

Če na zastopanost pogledamo še $\mathrm{z}$ drugega zornega kota in se vprašamo, katera skupina strokovnjakov je na katerem področju najbolj zastopana, si strokovnjaki glede na zastopanost po področjih sledijo takole:

Poklicno izobraževanje mladih (16 do 25 let)

- oblikovalci politike 65 odstotkov

- komentatorji 62 odstotkov

-izobraževalci 33 odstotkov

- raziskovalci 28 odstotkov

Poklicno izobraževanje zaposlenih in brezposelnih odraslih

- oblikovalci politike 81 odstotkov

-komentatorji 62 odstotkov

-izobraževalci 60 odstotkov

- raziskovalci 38 odstotkov

Osnovno izobraževanje odraslih

- oblikovalci politike 33 odstotkov

-komentatorji 23 odstotkov

- izobraževalci 18 odstotkov

- raziskovalci 10 odstotkov 


\begin{tabular}{lr}
\multicolumn{2}{l}{ Splošno, sociokulturno izobraževanje } \\
- izobraževalci & 42 odstotkov \\
- komentatorji & 39 odstotkov \\
- raziskovalci & 34 odstotkov \\
- oblikovalci politike & 33 odstotkov \\
\multicolumn{2}{l}{ Usposabljanje v podjetjih ali drugih delovnih } \\
organizacijah \\
-izobraževalci & 54 odstotkov \\
- oblikovalci politike & 52 odstotkov \\
- komentatorji & 46 odstotkov \\
- raziskovalci & 41 odstotkov \\
Izobraževanje na sploh & \\
- komentatorji & 38 odstotkov \\
-izobraževalci & 29 odstotkov \\
- politiki & 29 odstotkov \\
- raziskovalci & 24 odstotkov
\end{tabular}

\section{Kako so respondenti dejavni: koł prostovoljci, kot občasno zaposleni, kot redno zaposleni?}

Skoraj 92 odstotkov vseh respondentov je odgovorilo, da so trenutno (ali pa so bili) neposredno dejavni $v$ izobraževanju odraslih. Graf kaže, koliko dejavnih je bilo vključenih kot prostovoljcev, koliko kot občasno zaposlenih in koliko kot redno zaposlenih.

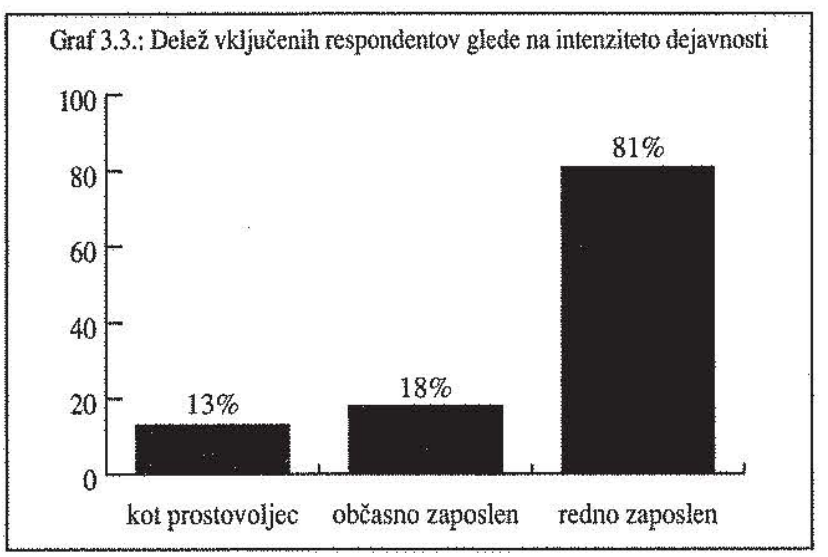

Če si podrobneje ogledamo odstotke udeleženosti v izobraževanju, vidimo, da variirajo od 100 odstotkov udeleženosti izobraževalcev, prek 97 odstotkov udeleženosti raziskovalcev in 92 odstotkov udeleženosti komentatorjev, do 86 odstotkov udeleženosti oblikovalcev politike.

Kot prostovoljci so se najpogosteje vkljucevali kot komentatorji (33 odstotkov), kot občasno zaposleni enako pogosto komentatorji in izobraževalci ( 25 odstotkov), kot redno zaposleni pa najpogosteje raziskovalci ( 89 odstotkov), sledijo pa jim izobraževalci ( 82 odstotkov).

\section{Starost in spol respondentov}

Kot nam kaže graf, je največ respondentov starih od 36 do 45 let, sledijo pa jim skoraj enako zastopani mlajši, stari do 35 let, in starejsi, stari od 46 do 55 let. Starejß̧ih od 55 let je le 15 odstotkov.

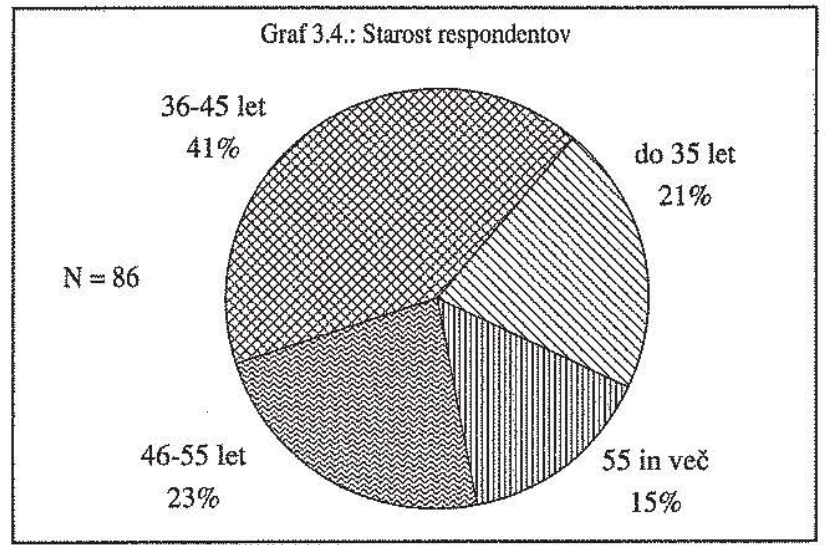

V skupini oblikovalcev politike izobraževanja je več kot polovica respondentov starih od 36 do 45 let, kar 82 odstotkov pa jih je starih od 36 do 55 let. Popolnoma enako število jih je $v$ najmlajši in najstarejši starostni skupini.

Raziskovalci so precej enakomemo razporejeni po vseh starostnih razredih, nekoliko več jih je le v starostni skupini 36 do 45 let ( 37 odstotkov).

Največ izobraževalcev, skoraj 40 odstotkov, je starih od 36 do 45 let, sicer pa so precej enakomerno razporejeni po starostnih skupinah.

Tudi komentatorjev je več kot polovica starih od 36 do 45 let (62 odstotkov) in od 46 do 55 let ( 23 odstotkov).

Moških je $v$ vzorcu nekoliko manj kot žensk, kar vsekakor izraža feminiziranost področja izobraževanja pri nas.

Poglejmo zastopanost po spolu glede na vlogo posameznika $v$ izobraževanju odraslih.

Med tistimi, ki odločajo o politiki izobraževanja, je kar 71 odstotkov moških. Tako razmerje je le v tej skupini, v drugih pa je razmerje mnogo bolj izenačeno. Tako je med raziskovalci moških le za nekaj odstotkov več kot žensk, 52 odstotkov, med izobraževalci pa je razmerje obmjeno in je žensk več ( 54 odstotkov).

Med komentatorii imajo večino moški, saj jih je 54 odstotkov.

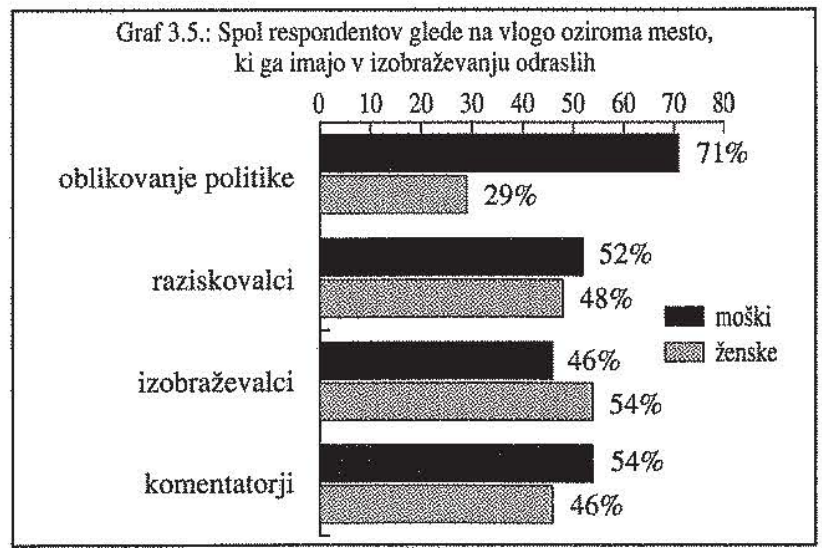

Kakšen je vpliv med starostjo, spolom in dejavnostjo na določenem področju izobraževanja odraslih?

Najbolj dejavni so na večini področij strokovnjaki, stari od 36 do 45 let. To velja tako za poklicno izobraževanje mladih in poklicno izobraževanje odraslih, za splošno, sociokulurno izobraževanje, usposabljanje in izobraževanje na splošno. Izjema je le osnovno izobraževanje odraslih, kjer prevladujejo respondenti, stari od 46 do 55 let. 
Najmlajši respondenti, stari do 35 let, so bili najbolj dejavni pri osnovnem izobraževanju odraslih (takih je bilo 30 odstotkov), sledi splošno, sociokulturno izobraževanje (20 odstotkov) ter izobraževanje na splošno (zastopani so bili z 20 odstotki).

Respondenti, stari od 36 do 45 let, so bili najbolj dejavni pri splošnem, sociokulturnem izobraževanju ( 53 odstotkov) in izobraževanju na splošno (to področje je izbralo 52 odstotkov respondentov).

Strokovnjaki, stari od 46 do 55 let, pa so izjavili, da so najbolj dejavni pri osnovnem izobraževanju odraslih (35 odstotkov), malo manj pa pri poklicnem izobraževanju mladih in odraslih.

Zadnja starostna skupina, v kateri so respondenti, ki so starejši od 55 let, je bila v poprečju manj dejavna od drugih skupin, najbolj dejavna pa je bila pri poklicnem izobraževanju zaposlenih in brezposelnih odraslih. spol.

Dejavnost na posameznih področjih se razlikuje tudi glede na

Tako je na področju poklicnega izobraževanja mladih in poklicnega izobraževanja odraslih moških več kot polovica, na področju osnovnega izobraževanja odraslih pa je žensk kar 76 odstotkov. Skoraj enako razmerje velja tudi za področje splošnega, sociokulturnega izobraževanja odraslih in za izobraževanje na splošno, kjer je žensk prav tako trikrat več kot moških. Številčno približno enako razmerje med spoloma je na področju usposabljanja.
Graf; Spolna struktura respondentov glede na področja njihove dejavnosti

pokl. izob. mladih

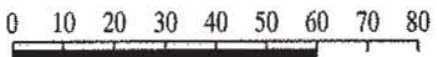

pokl. izob, odraslih

osnovno iz. odraslih

splošno izobr.

usposabljanje

izob. na splos̆no

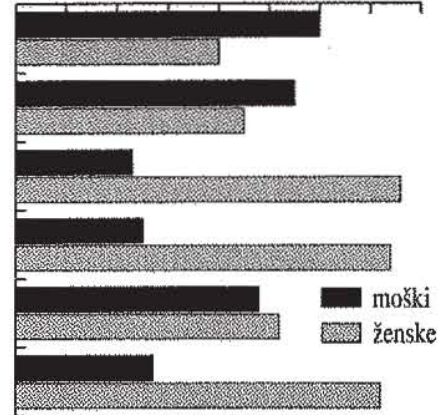

\section{Sklep}

$\mathrm{V}$ prispevku obravnavam metodološki pristop $\mathrm{k}$ raziskavi izbiro respondentov, oblikovanje vprašalnika in analizo dobljenih podatkov o respondentih, ki so sodelovali v raziskavi.

Del analize odgovorov pa $\mathrm{v}$ naslednjem prispevku podaja Nena Mijoč.

Sabina Jelenc

asistentka-stažistka na Filozofski fakulteti v Ljubljani 